\section{Hydrophobic Pockets in a Nonpolymeric Aqueous Gel: Observation of such a Gelation Process by Color Change**}

Uday Maitra,* Samrat Mukhopadhyay, Arnab Sarkar, Photon Rao, and S. S. Indi

\section{Dedicated to Professor Ronald Breslow on the occasion of his 70th birthday}

Studies on aqueous and organogels derived from low molecular mass species have been of considerable interest in recent years because of the many potential applications envisaged. ${ }^{[1]}$ While gel formation in aqueous and nonaqueous media by polymers and biopolymers is a well-documented phenomenon, ${ }^{[2]}$ detailed study of low molecular mass gelators has been embarked upon only during the past decade. Recently published examples of small molecule organogelators include steroids, ${ }^{[3]}$ carbohydrates, ${ }^{[4]}$ anthryl derivatives, ${ }^{[5]}$ and urea. ${ }^{[6]}$ We recently reported the first example of the gelation of organic fluids that was promoted by a donoracceptor interaction. ${ }^{[7]}$ Although there is a resurgence in the study of low molecular mass organogelators, there is little activity in the investigation of analogous hydrogelators. ${ }^{[8]}$ Herein we report that a novel tripoda ${ }^{[9]}$ cholic acid derivative $\mathbf{1}$ forms gels in aqueous media with remarkable efficiency, and that the gelation process creates highly hydrophobic pockets in a predominantly aqueous environment. We have also demonstrated for the first time the sol to gel transition for a nonpolymeric gel by a color change.

Our interests in bile acid based receptors ${ }^{[10]}$ for small organic molecules led us to the design of tripodal hosts derived from bile acids (1 and 2 ). These molecules are characterized by an anion-binding site ${ }^{[11]}$ on the "top" and multiple hydroxyl groups on the bile acid segment. Compounds $\mathbf{1}-\mathbf{3}$ were synthesized from readily available bile acids using standard procedures. ${ }^{[12]}$ We serendipitously discovered that compound $\mathbf{1}$ is a highly efficient gelator of aqueous acids, ${ }^{[13]}$ and leads to the formation of gels in many acidic solutions at remarkably low concentrations $(0.04 \% \mathrm{w} / \mathrm{v}$, $0.30 \mathrm{~mm}$ and above, that is, with one gelator molecule immobilizing more than $10^{5}$ water molecules!). Gels prepared with acetic acid/water were strong ${ }^{[14]}$ and transparent. The hydrochloride salt $(\mathbf{1} \cdot \mathrm{HCl})$ was prepared to determine if protonation of the tertiary nitrogen atom was important for

[*] Prof. Dr. U. Maitra, ${ }^{[+]}$S. Mukhopadhyay, A. Sarkar, Dr. P. Rao Department of Organic Chemistry

Indian Institute of Science

Bangalore 560012 (India)

Fax: (+91) 80-360-1968

E-mail: maitra@orgchem.iisc.ernet.in

Dr. S. S. Indi

Department of Microbiology and Cell Biology

Indian Institute of Science

Bangalore 560012 (India)

${ }^{+}$] Also: Chemical Biology Unit Jawaharlal Nehru Center for Advanced Scientific Research Bangalore (India).

[**] We thank the Jawaharlal Nehru Center for Advanced Scientific Research (Bangalore), and Mitokor, Inc. (San Diego) for supporting this work through unrestricted research grants.

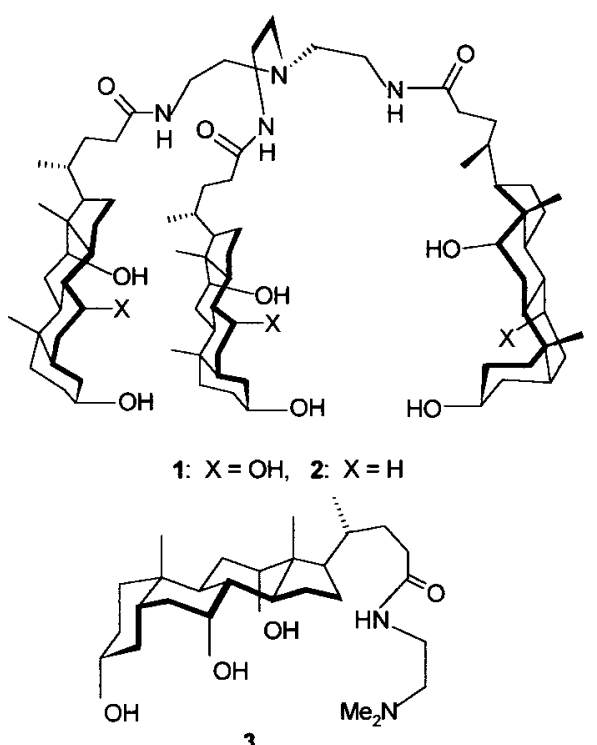

gelation. This salt was found to form a weak ${ }^{[14]}$ and slightly turbid gel in water. However, the addition of small amounts (8 to $10 \% \mathrm{v} / \mathrm{v}$ ) of an organic cosolvent (such as acetone, ethanol, methanol, or DMSO) led to the formation of strong and transparent gels. It appears that such mixed aqueous - organic media provide the correct hydrophobic-hydrophilic balance for optimum gelling conditions for $\mathbf{1} \cdot \mathrm{HCl}$. Gel to sol transition temperatures $\left(T_{\text {gel }}\right)$ were measured as a function of the concentrations of the gelator and acetic acid to get an estimate of the thermal stability of the gels (Figure 1). The value of $T_{\text {gel }}$ decreased at higher acetic acid concentrations, possibly as a result of the solubilizing effect of acetic acid.

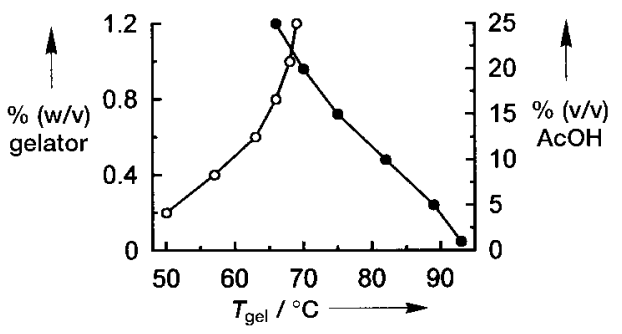

Figure 1. Variation of $T_{\text {gel }}$ as a function of the concentration of $\mathbf{1}$ in $20 \%$ $\mathrm{AcOH} / \mathrm{H}_{2} \mathrm{O}(\mathrm{O})$ and of $\mathrm{AcOH}(\bullet)$ at a constant $(7.5 \mathrm{~mm})$ concentration of $\mathbf{1}$

The morphology of the gel was examined by transmission electron microscopy (TEM; $\mathrm{OsO}_{4}$ staining) which showed a network structure composed of fibers with submicron dimensions (Figure 2). Electrostatic, hydrophobic as well as hydrogen-bonding interactions may be responsible for the aggregation, but how these fibers are constructed from the individual molecules is not understood at this stage. Closely related compound $\mathbf{2}$ and nontripodal structure $\mathbf{3}$ did not gel aqueous acids under identical conditions.

Since aggregation processes in aqueous media are predominantly driven by the hydrophobic effect, we thought it would be interesting to probe the gelation process using a hydrophobic fluorescent probe such as ANS. ${ }^{[15]}$ For this purpose a 


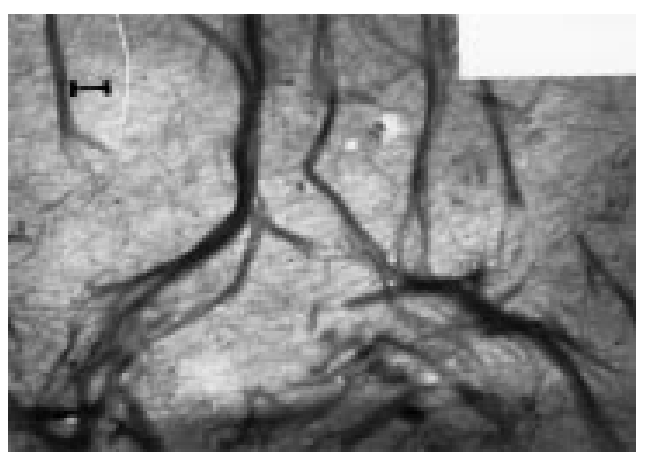

Figure 2. Transmission electron micrograph of a dried gel derived from $\mathbf{1}$ $\left(1 \% \mathrm{w} / \mathrm{v}\right.$ in $\left.20 \% \mathrm{AcOH} / \mathrm{H}_{2} \mathrm{O}\right)$ showing a fibrous network (scale bar: $1 \mu \mathrm{m}$ ).

solution of $\mathbf{1}$ in acetic acid was mixed with an aqueous ANS solution (final concentrations of $\mathrm{AcOH}, \mathbf{1}$, and ANS were $20 \% \mathrm{v} / \mathrm{v}, 5.25 \mathrm{~mm}$, and $10 \mu \mathrm{M}$, respectively) and the evolution of ANS fluorescence with time was monitored $\left(\lambda_{\mathrm{ex}} 365 \mathrm{~nm}\right.$, $\lambda_{\mathrm{em}} 475 \mathrm{~nm}$ ) at $26^{\circ} \mathrm{C}$. In the first few minutes (Figure 3 ) the

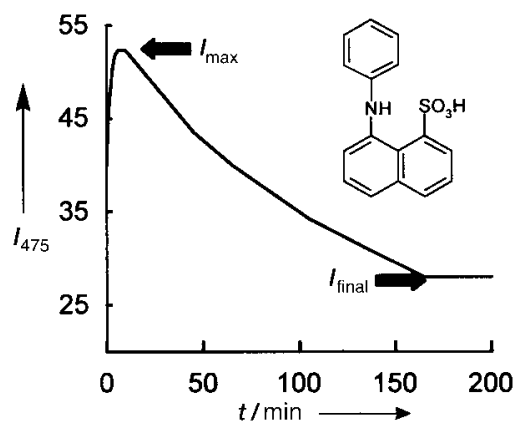

Figure 3. Time dependence of the ANS fluorescence during gelation of $\mathbf{1}$ in $20 \% \mathrm{AcOH} / \mathrm{H}_{2} \mathrm{O}$ at $26^{\circ} \mathrm{C}$. The final concentrations of $\mathbf{1}$ and ANS were $5.25 \mathrm{~mm}$ and $10 \mu \mathrm{M}$, respectively. $I_{475}=$ emission intensity at $475 \mathrm{~nm}$ relative to that of $10 \mu \mathrm{M}$ of ANS alone in $20 \% \mathrm{AcOH} / \mathrm{H}_{2} \mathrm{O}$. The structure of ANS is shown.

fluorescence rapidly increased to reach a maximum $\left(I_{\max }\right.$, "intermediate state"), then it decreased at a slower rate. Practically no change in the emission intensity $\left(I_{\text {final }}\right.$, "gel state") was observed after $3 \mathrm{~h}$, which suggested completion of the gelation process. ${ }^{[16,17]}$ From the time course of the ANS fluorescence during gelation it seems likely that the gelation process proceeds via an intermediate state of aggregation, where ANS has a higher binding affinity than the final gel state.

The mere presence of $\mathbf{1}$ in solution in neat $\mathrm{AcOH}$ or $\mathrm{EtOH}$, or below the critical gelling concentration $(<0.10 \% \mathrm{w} / \mathrm{v}$ in $20 \% \mathrm{AcOH} / \mathrm{H}_{2} \mathrm{O}$ ) did not enhance the fluorescence of ANS relative to the values for ANS measured in the corresponding solvents in the absence of $\mathbf{1}$. The enhancement of fluorescence intensity for $5.25 \mathrm{~mm}$ of gelator $\mathbf{1}$ in $20 \% \mathrm{AcOH} / \mathrm{H}_{2} \mathrm{O}$ was 50 fold at the intermediate state and 30 fold at the final gel state (both measured relative to the fluorescence of ANS in $20 \% \mathrm{AcOH} / \mathrm{H}_{2} \mathrm{O}$, Figure 3). We feel that the unusual enhancement of hydrophobicity is the result of the formation of networks having highly hydrophobic cavities and/or clefts in which ANS is accommodated. The hydrophobicity in these pockets of the gel network is clearly much higher than the interior of $\beta$-cyclodextrin. ${ }^{[18]}$

These studies suggested that it should be possible to visualize the sol to gel transition using a suitable dye whose $\mathrm{p} K_{\mathrm{a}}$ value is close to the bulk $\mathrm{pH}$ value of the gel (ca. 4), and in which the two forms of the indicator bind differentially to the hydrophobic pockets. We found that on addition of the sodium salt of bromophenol blue (BPB) to a solution of $\mathbf{1}$ in $\mathrm{AcOH} / \mathrm{H}_{2} \mathrm{O}$ (final concentrations of $\mathbf{1}, \mathrm{BPB}$, and acetic acid were $7.50 \mathrm{~mm}, 0.37 \mathrm{~mm}$, and $25 \% \mathrm{v} / \mathrm{v}$, respectively) the color of the mixture changed from yellow in the sol phase to green upon gelation. The absorption spectrum of the sol showed a peak at $620 \mathrm{~nm}$ which intensified on gelation while the intensity of the peak at $430 \mathrm{~nm}$ decreased (Figure 4). The

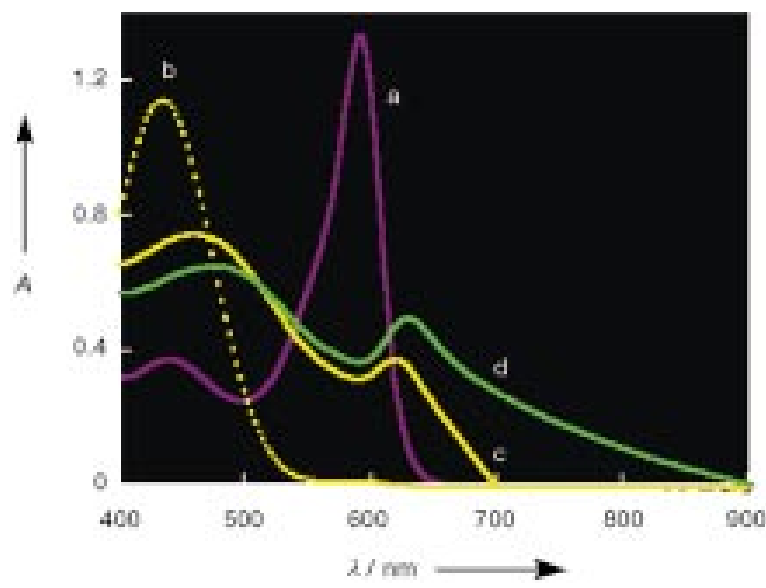

Figure 4. Absorption spectra $\left(26^{\circ} \mathrm{C}\right)$ of the sodium salt of bromophenol blue $(0.37 \mathrm{~mm})$ : a) in neutral water, b) in $\left.25 \% \mathrm{AcOH} / \mathrm{H}_{2} \mathrm{O}, \mathrm{c}\right)$ in the presence of $1(5.25 \mathrm{~mm})$ in $25 \% \mathrm{AcOH} / \mathrm{H}_{2} \mathrm{O}$ (before forming a gel) and d) after forming a gel. The sample colors closely resemble the colors used in the plots. $A=$ absorbance.

intensity ratio $I_{620} / I_{430}$ changed from 0.5 in the sol to 0.8 in the gel which indicated a perturbation of the equilibrium between the neutral and the ionized forms of the indicator. We believe that the conversion of the $\mathrm{sp}^{3}$ center in the neutral form of $\mathrm{BPB}$ to an $\mathrm{sp}^{2}$ center in the ionized form makes the species more planar, and this form is more easily accommodated in the hydrophobic pocket (Scheme 1). This hypothesis is supported by the fact that induced circular dichroism (CD)<smiles>O=S1(=O)OC(c2cc(Br)c(O)c(Br)c2)(c2cc(Br)c(O)c(Br)c2)c2ccccc21</smiles><smiles>O=C1C(Br)=CC(=C(c2cc(Br)c(O)c(Br)c2)c2ccccc2[N+](=O)[O-])C=C1Br</smiles>

$$
\begin{aligned}
& \text { Yellow at } \mathrm{pH} 3.0 \\
& \lambda_{\max }=420 \mathrm{~nm}
\end{aligned}
$$

Blue at $\mathrm{pH} 4.6$ $\lambda_{\text {max }}=589 \mathrm{~nm}$ 
of BPB is observed for the peak at $620 \mathrm{~nm}$ (in the gel state), but not for the peak at $430 \mathrm{~nm}$ (Figure 5). This CD band around $620 \mathrm{~nm}$ is substantially reduced in intensity on gel to sol transition which implies that these pockets created in the gel network have chiral influence on the bound achiral species in the gel state.

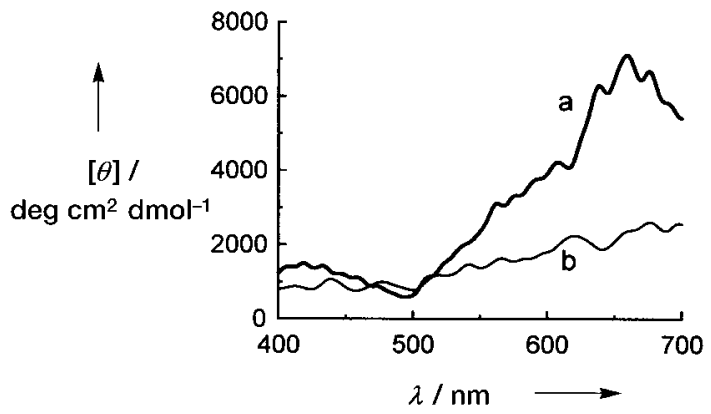

Figure 5. Induced circular dichroism of bromophenol blue in the a) gel state at $20^{\circ} \mathrm{C}$ and b) sol state at $70^{\circ} \mathrm{C}$. Concentrations of bromophenol blue and the gelator $\mathbf{1}$ are $0.37 \mathrm{~mm}$ and $7.50 \mathrm{~mm}$, respectively. $[\theta]=$ Molar ellipticity.

In conclusion, we have discovered a novel and highly efficient tripodal cholic acid derived gelator showing unusual aggregation properties that lead to the gelation of aqueous fluids. Structural details of hydrophobic pockets formed in the gel remain to be elucidated, but it is likely that lipophilic $\beta$ faces of the cholic acid backbone associate to form the hydrophobic pockets. Detailed structure-property relationship on this new class of molecules, and further studies on gels from this novel molecule are currently in progress. We are also examining the possibility of utilizing the chiral hydrophobic pockets formed in the gel for carrying out selective chemical transformations.

Received: January 2, 2001 [Z16353]

[1] a) J. Prost, F. Rondelez, Nature 1991, 350, 11; b) P. Terech, R. G. Weiss, Chem. Rev. 1997, 97, 3133; c) J. van Esch, B. L. Feringa, Angew. Chem. 2000, 112, 2351; Angew. Chem. Int. Ed. 2000, 39, 2263.

[2] J. M. Guenet, Thermoreversible Gelation of Polymers and Biopolymers, Academic Press, New York, 1992.

[3] a) R. Mukkamala, R. G. Weiss, J. Chem. Soc. Chem. Commun. 1995, 375; b) Y.-C. Lin, B. Kachar, R. G. Weiss, J. Am. Chem. Soc. 1989, 111, 5542; c) Y. Hishikawa, K. Sada, R. Watanabe, M. Miyata, K. Hanabusa, Chem. Lett. 1998, 795; d) J. H. Jung, Y. Ono, K. Hanabusa, S. Shinkai, J. Am. Chem. Soc. 2000, 122, 5008 .

[4] a) P. Vassil, E. E. Simanek, M. R. Wood, C.-H. Wong, Chem. Commun. 1998, 1865; b) R. J. H. Hafkamp, M. C. Feiters, R. J. M. Nolte, J. Org. Chem. 1999, 64, 412.

[5] T. Brotin, R. Utermöhlen, F. Fages, H. Bouas-Laurent, J.-P. Desvergne, J. Chem. Soc. Chem. Commun. 1991, 416.

[6] a) F. S. Schoonbeek, J. van Esch, R. Hulst, R. M. Kellogg, B. L. Feringa, Chem. Eur. J. 2000, 6, 2633; b) For a recent report on the gelation of $\mathrm{CO}_{2}$, see C. Shi, Z. Huang, S. Kilic, J. Xu, R. M. Enick, E. J.
Beckman, A. J. Carr, R. E. Melendez, A. D. Hamilton, Science 1999, 286, 1540.

[7] U. Maitra, P. V. Kumar, N. Chandra, L. J. D’Souza, M. D. Prasanna, A. R. Raju, Chem. Commun. 1999, 595.

[8] a) A. Rich, D. M. Blow, Nature 1958, 182, 423; b) G. R. Newkome, G. R. Baker, S. Arai, M. J. Saunders, P. S. Russo, K. J. Theriot, C. N. Moorefield, L. E. Rogers, J. E. Miller, T. R. Lieux, M. E. Murray, B. Phillips, L. Pascal, J. Am. Chem. Soc. 1990, 112, 8458; c) P. Terech, W. G. Smith, R. G. Weiss, J. Chem. Soc. Faraday Trans. 1996, 92, 3157; d) S. Bhattacharya, S. N. G. Acharya, Chem. Mater. 1999, 11, 3504; e) L. A. Estroff, A. D. Hamilton, Angew. Chem. 2000, 112, 3589; Angew. Chem. Int. Ed. 2000, 39, 3447; f) F. M. Menger, K. L. Caran, J. Am. Chem. Soc. 2000, 122, 11679; g) P. Pfannemüller, W. Welte, Chem. Phys. Lipids 1985, 37, 227.

[9] For tripodal gelators of organic fluids, see a) J.-E. S. Sohna, F. Fages, Chem. Commun. 1997, 327; b) M. de Loos, A. G. J. Ligtenbarg, J. van Esch, H. Kooijman, A. L. Spek, R. Hage, R. M. Kellogg, B. L. Feringa, Eur. J. Org. Chem. 2000, 3675.

[10] a) L. J. D'Souza, U. Maitra, J. Org. Chem. 1996, 61, 9494; b) U. Maitra, P. Rao, P. V. Kumar, R. Balasubramanian, L. Mathew, Tetrahedron Lett. 1998, 39, 3255; c) P. Rao, U. Maitra, Supramol. Chem. 1998, 9 , 325; d) V. K. Potluri, U. Maitra, J. Org. Chem. 2000, 65, 7764.

[11] S. Valiyaveettil, J. F. J. Engbersen, W. Verboom, D. N. Reinhoudt, Angew. Chem. 1993, 105, 942; Angew. Chem. Int. Ed. Engl. 1993, 32, 900

[12] Selected data for compound 1: ${ }^{1} \mathrm{H}$ NMR $\left(300 \mathrm{MHz}, \mathrm{CDCl}_{3}\right): \delta=0.68$ (s, 9H), $0.88(\mathrm{~s}, 9 \mathrm{H}), 1.05(\mathrm{~d}, 5.7 \mathrm{~Hz}, 9 \mathrm{H}), 1.24(\mathrm{brs}, 6 \mathrm{H}), 1.51-1.75$ (brm), 2.13 (brs, 6H), 3.43 (m, 3H, 3- $\beta$ H's), 3.82 (m, 3H, 7- $\beta$ H's), 3.96 (m, 3H, $12-\beta$ H's), 6.92 (brs, amide H's); ${ }^{13} \mathrm{C}$ NMR $(75 \mathrm{MHz}$, [D 6 DMSO): $\delta=12.4,17.1,19.1,22.6,22.8,26.2,27.3,28.6,30.4,30.5$ $31.7,32.7,34.4,34.9,35.2,36.9,41.3,41.5,45.8,46.3,62.8,66.3,67.8$, 70.4, 71.0, 172.7; matrix-assisted laser desorption/ionization time-offlight (MALDI-TOF) MS: 1318.2 (calcd for $\mathrm{C}_{78} \mathrm{H}_{132} \mathrm{~N}_{4} \mathrm{O}_{12}$ 1317.9). Elemental analysis (\%) calcd for $\mathrm{C}_{78} \mathrm{H}_{132} \mathrm{~N}_{4} \mathrm{O}_{12} \cdot 5 \mathrm{H}_{2} \mathrm{O}$ (1408.00): $\mathrm{C}$ $66.58, \mathrm{H} 10.16, \mathrm{~N} 3.98$; found: C $66.84, \mathrm{H} 9.89, \mathrm{~N} 3.55$.

[13] In a typical gelation experiment $\mathbf{1}(5 \mathrm{mg})$ was dissolved in acetic acid $(100 \mu \mathrm{L})$. Water $(400 \mu \mathrm{L})$ was added slowly and then the mixture was allowed to stand. After a few minutes a colorless and transparent gel was obtained. At lower percentages of acetic acid the gels were somewhat translucent.

[14] Gels formed in $10 \mathrm{~mm}$ i.d. pyrex test tubes could not be dislodged by vigorous shaking. Those gels which are highly viscous fluids we term "weak" gels.

[15] ANS (8-anilinonaphthalene-1-sulfonic acid) is practically nonfluorescent in water, but it becomes highly fluorescent in apolar environments. See: J. R. Lakowicz, Principles of Fluorescence Spectroscopy, Plenum, New York, 1983.

[16] A control experiment performed under the same condition using a nongelling concentration $\left(0.04 \% \mathrm{w} / \mathrm{v}\right.$ in $\left.20 \% \mathrm{AcOH} / \mathrm{H}_{2} \mathrm{O}\right)$ of $\mathbf{1}$ did not show any change in the fluorescence as a function of time.

[17] This plot has a striking similarity to the refolding kinetics of human $\alpha$ lactalbumin probed with ANS in which the emission intensity increases to a maximum at the "molten globular state" of the protein which is characterized by loose hydrophobic cavities_although the time scale of our gelation process is much longer. G. V. Semisotnov, N. A. Rodionova, O. I. Razgulyaev, V. N. Uversky, A. F. Gripas, R. I. Gilmanshin, Biopolymers 1991, 31, 119.

[18] A 10 fold increase in the ANS fluorescence was observed in going from bulk water to the internal cavity of $\beta$-cyclodextrin (F. Cramer, W. Saenger, H.-C. Spatz, J. Am. Chem. Soc. 1967, 89, 14). See also H.-J. Schneider, A. K. Yatsimirsky, Principles and Methods in Supramolecular Chemistry, Wiley, New York, 1999. 